\title{
Antioxidant and antidiabetes activity from the fruit shell of Calophyllum inophyllum
}

\author{
Jamilah Abbas*, Minarti Minarti, and Nina Artanti \\ Research Center for Chemistry - National Research and Innovation Agency, Kawasan PUSPIPTEK, Serpong - \\ 15314, South Tangerang, Banten, Indonesia. \\ *Corresponding author : jamlahabbas@yahoo.com
}

\begin{tabular}{|c|c|}
\hline ARTICLE INFO & ABSTRACT \\
\hline $\begin{array}{l}\text { Article History: } \\
\text { Received date: } 19 \text { June } 2021 \\
\text { Revised date: } 22 \text { October } 2021 \\
\text { Accepted date: } 02 \text { November } 2021 \\
\text { Available online at: November } 2021\end{array}$ & \multirow{2}{*}{$\begin{array}{l}\text { The purpose of this study was to explore the antioxidant and } \\
\text { antidiabetes activity of the Calophyllum inophyllum fruit shell. } \\
\text { Hexane fraction from fruit shell of C. inophyllum was prepared } \\
\text { and separated by column chromatography methods. The hexane sub } \\
\text { fractions (SF1 and SF2) was analysed using DPPH (2.2-diphenyl- } \\
\text { 1-picrylhydrazyl radical scavenging) for antioxidant activity and } \\
\text { inhibition of } \alpha \text {-glucosidase enzyme for antidiabetes activity. The } \\
\text { sub fractions from fruit shell of C. inophyllum showed moderate } \\
\text { antioxidant and antidiabetes activity, although the activities were } \\
\text { low. The SF1 had only antidiabetes activity with } 16.26 \% \text { inhibition } \\
\text { of } \alpha \text {-glucocidase enzyme at } 100 \mu \mathrm{g} / \mathrm{ml} \text {. The SF } 2 \text { showed antioxidant } \\
\text { and antidiabetes activity with } 6.31 \% \text { inhibition of DPPH and } 16.99 \% \\
\text { inhibition of } \alpha \text {-glucocidase enzyme at } 100 \mu \mathrm{g} / \mathrm{ml} \text {, respectively. }\end{array}$} \\
\hline $\begin{array}{l}\text { Keywords: } \\
\text { Calophyllum inophyllum, fruit } \\
\text { shell, antioxidant, antidiabetes }\end{array}$ & \\
\hline & $\begin{array}{l}\text { (C) } 2016 \text { Indonesian Journal of Applied Chemistry. This is an open access } \\
\text { article under the CC BY-NC-SA license (https://creativecommons.org/ } \\
\text { licenses/by-nc-sa/4.0/). }\end{array}$ \\
\hline
\end{tabular}

\section{INTRODUCTION}

C. inophyllum is a large genus in Gutteferae family with about 180-200 species, which is distributed mainly in tropical forests such as China South and Southeast Asia, Eastern Africa, Madagascar, the Pacific island, America, Australia and Brazil. Calophyllum species are large hardwood and are generally grown in a mountain forest to coastal swamps. The genus Calophyllum has potential for timber and as folk medicines for various diseases such as vaginal discharge, rheumatism, scabies, ulcers, and hair grower [1,2].

In 2016, Li et al. have successfully isolated four coumarins compounds i.e. (-)-12-methoxy inophyllum $\mathrm{A},(+)-12$-methoxy inophyllum $\mathrm{H}-1$, (-)-12-methoxyIinophyllum $\mathrm{H}-2$ and, inophyllum H-J from C.inophyllum leaves [2]. Susanto et al. have analyzed proximate content : i.e. moisture, ash, protein, crude fiber, carbohydrate, mineral and also identified 3 compounds i.e. trans-2[2(trifluoromethyl) phenyl]-10b, 10c-dimethyl-10b and 10c-dihydropyren from C.inophyllum leaves [3]. Dipyranocoumarin has been isolated from callus of C.inophyllum Lin, that pyranocoumarin have anti-HIV activity [4]. Ze, Qi Xu [5] proved that Calanolide A is active against both drugsusceptible and drug-resistant strains of Mycobacterium tuberculosis.

Many researchers have also observed the activity of some species of Calophyllum as anti cytotoxic [6], antimalaria [7], antimicrobial [8], antibacterial [9] toxicology effect [10] and antiulcer [11] and, anti-inflammatory activity [12]. She et al. have isolated inocalophyllins 
A, B compound and their methyl ester from the seed of C.inophyllum [13]. Unfortunately research on the use of fruit shell of C.inophyllum (FSCI) has never been conducted. Therefore this research was importantly conducted to evaluate the antioxidant and antidiabetic activities of fruit shells from C. inophyllum (FSCI). C. inophyllum fruit shells were considered as waste material from the process of extracting oil from the fruit of $C$.inophylum. The production of oil from C. inophyllum fruit was available in Indonesia. Therefore we used waste material from $C$. inophyllum fruit shells to explore the antioxidant and antidiabetes activity for the possibility of being used as a source for medicines.

\section{EXPERIMENTAL}

\subsection{Materials}

The fruits of $C$. inophyllum were obtained from Puspiptek Garden, Serpong, West Java, Indonesia. Indonesia. C.inophyllum plants in Puspiptek area were planted by Research Center for Biology LIPI and the plant name was confirmed by the botanist of Research Center for Biology - LIPI. Solvents used for extraction and column chromatography (n-hexane, ethyl acetate, acetone, and methanol) were purchased from local market and distilled prior to use. Folin-Ciocalteu Reagent, $\mathrm{FeCl}_{3}$, DPPH (2,2-diphenyl-1-picrylhydrazyl), gallic acid, and quercetin were purchased from Sigma-Aldrich (St. Louis, USA). TLC plates (silica gel $60 \mathrm{~F}_{254}$ thin $0.25 \mathrm{~mm}, 20 \times 20 \mathrm{~cm}$ ) and silica gel G 60. (70-230 mesh) for column chromatographic were purchased from Merck.

\subsection{Methods}

\subsubsection{Extraction and fractionation}

The fresh fruit samples were chopped into two pieces then were separated into fruit peel, fruit shell and fruit core before finely cut. Image of C. inophyllum fruit shell (CIFS) shown in Fig. 1. The CIFS were dried at $45^{\circ} \mathrm{C}$ then grinded using Laboratory Mill grinder.

The powder of CIFS $(0.5 \mathrm{~kg})$ was extracted with $3 \mathrm{~L}$ of $n$-hexane, ethyl acetate and methanol for $72 \mathrm{~h}(\mathrm{n}=3 \mathrm{x})$. Then, the solutions were filtered, then evaporated under reduced pressure to give $n$-hexane, ethyl acetate and methanol crude extract are $64.215 \mathrm{~g}: 66.929 \mathrm{~g}$ and $101.387 \mathrm{~g}$ respectively.

The $n$-hexane extract $(50.0 \mathrm{~g})$ was fractionated on silica gel column. The column was eluted by using $n$-hexane and EtOAc with increasing polarity. Fractions were collected and combined on the basis of TLC analysis. The TLC plate was visualized by spraying with $5 \% \mathrm{v} / \mathrm{v}_{2} \mathrm{SO}_{4}$ in methanol and Folin-Ciocalteu reagent in methanol. Based on the results of the TLC analysis, the fractions that gave the same results were combined, so that two sub-fractions were obtained, namely SF1 and SF2. These two sub fractions were analyzed for the total phenolic content, total flavonoid content, antioxidant activity and also antidiabetic activity.

\subsubsection{Total Phenolic Content (TPC)}

TPC of the SF1 and SF2 fraction from C.inophyllum were identified using the Folin Ciocalteu method. Briefly, the sample solution

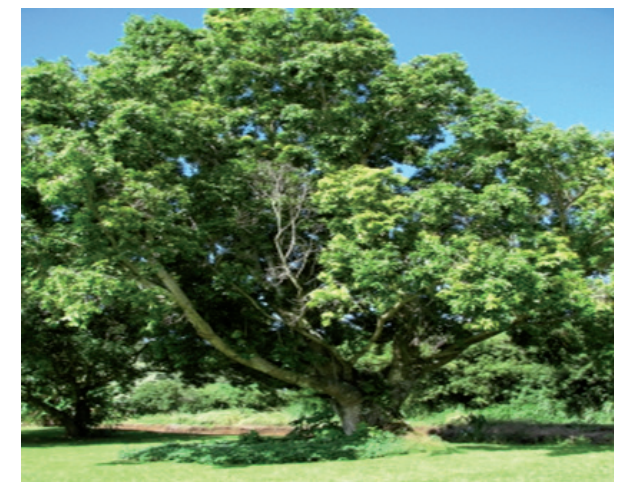

(a)

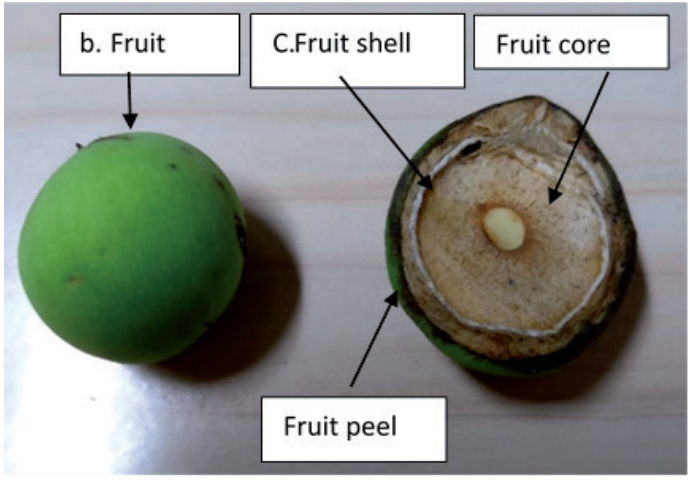

(b)

Figure 1. C. inophyllum tree (a), fruit (b) and fruit shell (c) 
( $2 \mu 1$ of SF 1 , SF2 extracts or standard solution of gallic acid at different concentrations $(5,10$, $15,20,25,30,40,50 \mu \mathrm{g} / \mathrm{mL})$ were combined with $10 \mu \mathrm{l}$ Folin Ciocalteu, followed by $158 \mu \mathrm{l}$ of deionized water into a 96-well microplate. After 8 minutes was added $30 \mu 1$ of $20 \%$ sodium carbonate $\left(\mathrm{Na}_{2} \mathrm{CO}_{3}\right)$ (total volume $200 \mu \mathrm{L}$ ). Then, the mixture was incubated for 2 hours at room temperature. The formation of the blue color solution was measured at $765 \mathrm{~nm}$ against a blank consisting of deionized water and Folin Ciocalteu reagent using a Thermo Scientific Varioskan Spectrophotometer. Total phenolic contents were expressed as mg gallic acid equivalent (GAE) per gram of extract by computing with standard calibration curve. The TPC was performed in duplicate and the results were expressed as average $[14,15]$

\subsubsection{Total Flavonoid Content}

Determination of the total flavonoid content (TPC) in SF21, SF2 fraction from C.inophyllum was done by using aluminium chloride $\left(\mathrm{AlCl}_{3}\right)$ assay. Briefly, a volume of SF1 and SF2 extracts or standard quercetin each $20 \mu$ ranging 5 to 50 $\mu \mathrm{g} / \mathrm{mL}$ were mixed with $100 \mu \mathrm{l}$ of deionized water and $6 \mu 1 \mathrm{NaNO}_{2}$ solution (5\%) were then vortexed for $10 \mathrm{~s}$ and left at room temperature for $5 \mathrm{~min} .12 \mu \mathrm{AlCl}_{3}(10 \% \mathrm{w} / \mathrm{v}$ in water) was added followed by $40 \mu \mathrm{l} \mathrm{NaOH}(1 \mathrm{mM})$ and $22 \mu \mathrm{l}$ of distilled water in a 96-well microplate (total volume $200 \mu \mathrm{L}$ ) After 15 min incubation at room temperature, the absorbance was measured at $510 \mathrm{~nm}$ using a microplate reader. Quercetin 5 to $50 \mu \mathrm{g} / \mathrm{ml}$ were used as standard. The total flavonoid content were expressed as mg quercetin equivqlent $(\mathrm{QE})$ per gram extract $[15,16]$

\subsubsection{Antioxidant activity}

2,2-Diphenyl-2-picrylhydrazyl (DPPH) was used to evaluate radical scavenging activity according to the procedure described in previous areferences $[17,18,19]$. The samples were dissolved in methanol and $20 \mu \mathrm{L}$ aliquot of different sample concentrations was mixed with $50 \mu 1$ of DPPH solution $(0.2 \mathrm{mM}$ in methanol). Methanol was added up to $200 \mu 1$ to give different concentrations of the samples in the 96-well microplate, incubated for $30 \mathrm{~min}$.
The absorbance was measured at $517 \mathrm{~nm}$ by using a microplate reader (Thermo Scientific Varioskan $\left.{ }^{\circledR}\right)$.

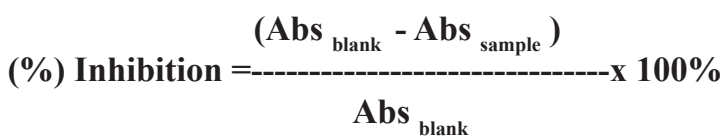

\subsubsection{Antidiabetes activity test.}

The antidiabetes activity in SF 1 and SF 2 of fruit shell from $C$. inophyllum was measured as the inhibitory activity for $\alpha$-glucosidase using the method reported by Da Silva Pinto et al. 2008 (15) with minor modification. A $0.25 \mathrm{mg} \alpha$ - glucocidase was dissolved in $10 \mathrm{ml}$ buffer phosphate (pH 7) containing $20 \mathrm{mg}$ albumin serum bovine. The enzyme was diluted 10 times before used for assay. The assay mixtures were as follow $250 \mu 1$ p-Nitrophenyl- $\alpha$-D-glucopyranoside $(5 \mathrm{mM})$ was added to $495 \mu 1100 \mathrm{mM}$ buffer phosphate $(\mathrm{pH}$ 7) and added $5 \mu 1$ sample in DMSO (1\%, $0.5 \%$ and $0.25 \%$ ) and yeast $\alpha$-glucosidase $250 \mu 1$ $(0.065$ units $/ \mathrm{mL})$ was used as the enzyme. Incubated at $37^{\circ} \mathrm{C}$ for 5 minutes, then added $25 \mu \mathrm{l}$ enzyme, incubated 15 minutes. Reaction was stopped by using $1 \mathrm{~mL} 200 \mathrm{mM} \mathrm{Na}_{2} \mathrm{CO}_{3} \cdot \alpha$ -glucosidase inhibitory activity was conducted at sample concentrations of $0.25,0.5$ and $1 \%$. The inhibitory effect on $\alpha$-glucosidase activity was determined by measuring the amount of p-nitrophenol released at $400 \mathrm{~nm}$ using $\mathrm{UV}$-Vis Spectrometer [20,21].

[(Ac(o)-Ac (t)]- (As-Ab)

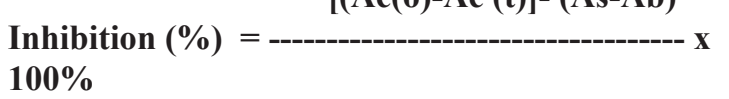

$(\mathbf{A s}-\mathbf{A b})$

\section{RESULT AND DISCUSSION}

\subsection{Extraction and Fractionation}

Fractionation of CIFS n-hexane extract using silica column chromatography with hexane and ethyl acetate solvents with increasing polarity resulted in 50 fractions. After being analyzed by TLC, fraction 10-13 were combined as sub fraction 1 (SF1) and fraction 43-50 were combined as SF2 which further analysed. 


\subsection{Total Phenolic and Total Flavonoid Content}

Fig 2. shows total phenolic content and total flavonoid content of in SF 1 and SF 2 of fruit shell from $C$. inophylum $n$-hexane extract. Each value in the graph is represented as mean $(\mathrm{n}=2)$. Total flavonoid contents in both sub fractions were higher than total phenolic contents. These results were similar with the reported results from the leaf extract of $C$. inophyllum [15] but none of those studies used fruit shell part and n-hexane as solvent .

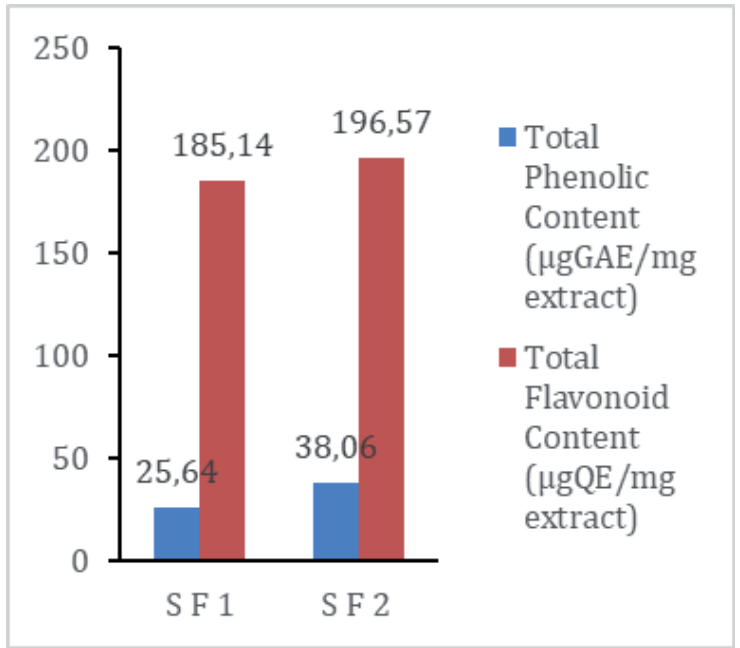

Fig 2. Total phenolic and flavonoid content of SF1 and SF2

\subsection{Antioxidant and Antidiabetes activities}

The DPPH free radical scavenging activity The DPPH free radical scavenging activity measured the ability of the sample to donate hydrogen to the DPPH radical, resulting in bleaching of the stable DPPH free radical from the purple colour of DPPH cation to the yellow-colored diphenyl picryl hydrazine. The greater the bleaching action observed, the higher the antioxidant activity, which is reflected in a lower $\mathrm{IC}_{50}$ [17]. The in vitro antidiabetes activity were conducted by $\alpha$-glucosidase inhibitory activity method. Figure 3 show the results scavenger free radical DPPH and as $\alpha$-glucosidase inhibitor activities of SF 1 and SF 2 from C.inophyllum fruit shell $\mathrm{n}$-hexane extract at concentration of $100 \mu \mathrm{g} /$ $\mathrm{ml}$. At this concentration SF1 did not show any antioxidant activity whereas SF2 showed low antioxidant activity. Both subfractions (SF1 and SF2) showed almost the same $\alpha$-glucosidase inhibitory activity. Results reported here are relatively lower when compared to antioxidant and antidiabetes results reported in other C. inophyllum studies $[8,19,20,21]$. It is suspected that compounds containing hydroxyl groups such as calanone, coumarin and xanthones compounds and unsaturated fatty acids such as palmitoleic acid have antidiabetic activity. These suspected compounds might be present in low quantities in SF 1 and SF 2 from C. inophyllum fruit shell n-hexane fractions. Whereas in those other $C$. inophyllum studies which used different plant parts and extracted with water (hydrodistillation) and methanol, the suspected compounds might be present in much higher quantities. None of those studies used fruit shell part and $n$-hexane as solvent, that might explain the difference in the antioxidant and andiabetes activities with our results.

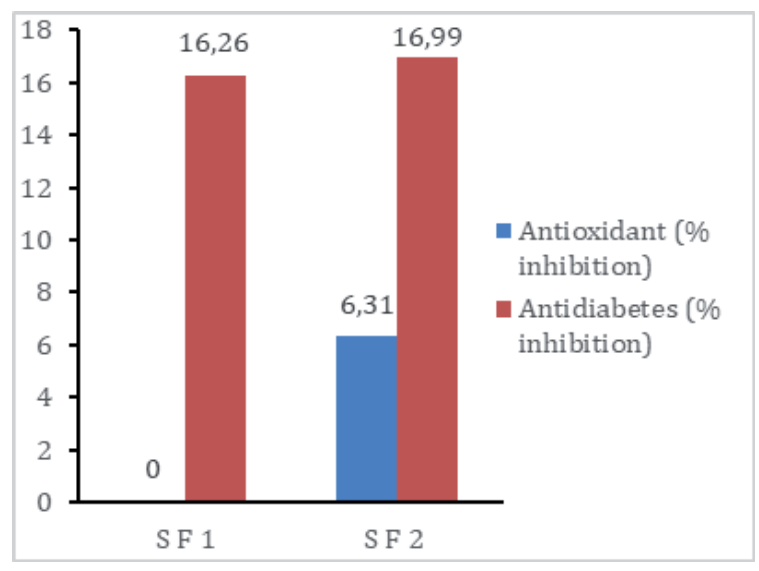

Fig 3. Antioxidant and antidiabetes activities of SF1 and $\mathrm{SF} 2$ at $100 \mu \mathrm{g} / \mathrm{ml}$.

\section{CONCLUSION}

The phytochemical screening from n-hexane fraction of fruit shell C. inophyllum namely SF1 and SF2 showed that both contained higher total flavonoid contents compared to total phenolic content. Antioxidant test using DPPH method showed that at $100 \mu \mathrm{g} / \mathrm{ml} \mathrm{SF} 1$ did not have antioxidant activity and SF 2 have antioxidant activity with inhibition of $6.31 \%$. The. Antioxidant test using DPPH method showed that at $100 \mu \mathrm{g} /$ $\mathrm{ml} \mathrm{SF} 1$ did not have antioxidant activity and SF 
2 have antioxidant activity with inhibition of 6.31

$\%$. The result of the antidiabetes showed that at $100 \mu \mathrm{g} / \mathrm{ml} \mathrm{SF} 1$ and SF2 have $16.26 \%$ and 16.99 $\%$ inhibition $\alpha$-glucosidase activity, respectively. Although relatively low, so far that we are aware this is the first report about antioxidant activity and a-glucosidase inhibition of n-hexane fraction of fruit shell of C. inophyllum. Therefore SF1 and SF2 might not be too suitable for the source to obtain antioxidant and antidiabetes compounds compared to other reported parts of C. inophyllum. Since fruit shells of $C$. inophyllum as waste materials are available in large quantities, studies to explore other bioactivities should be conducted for utilization as a source for medicine development.

\section{ACKNOWLEDGMENT}

This research was supported by INSINAS (Insentif Research innovasi National/Innovation System Incentive Program) 2017 for financial support which funding the current project under a schema (09/INS/PPK/E/E4/2017) and Indonesian Institute of Science for research facilities. The authors are also thankful to all of the lab members for support to this research and for technical assistance.

\section{REFERENCES}

[1] N.I. Aminuddin, F. Ahmad, Z.M Taher and R.M. Zulkifli (2016). Four new-substituted coumarins from Calophyllum incrasaptum and their biological activities. Phytochemistry Letter16, pp 208-293.

[2] Z.L. Li, Y.Q. Li, N.B. Qin, D.H. Li, .Z.G. Liu, Q. Liu and H.M. Gua. (2016). Four new coumarin from the leaves of Calophyllum.inophyllum. Phytochemistry Letter. 16, pp. 203-206.

[3] D.F. Susanto, H.K., A. Aparamarta, A. Widjaya and S. Gunawan. (2017). Identification of phytochemical compounds in Calophyllum inophyllum leaves. Asian Pasific Journal of Tropical Biomedicine. 7 (9), pp. 773-778.

[4] K.D. Pawar, S.P. Joshi, S.R. Bhide, and S.R. Thengane. (2007). Parent of anti-HIV dipyranocoumarin expression in callus.

[5] cultures of Calophyllum inophyllum." Journal of Biotechnology. 130, pp. 346-353.
[6] Q.X. Ze, W.B Wlliam, J.S. William. ing (Nov. 14, 2003). Anti-HIV natural product (+)-calanolide $\mathrm{A}$ is active against both drug-susceptible and drug-resistant strains of Mycobacterium tuberculosis. Bioorganic \& Medicinal Chemistry. 12, pp. 1199-1207.

[7] F. Laopian. (2019). Caloxanthones A-C, three new xanthones from the roots of Calophyllum calaba and the cytotoxicity. Natural Product Research. 33(11), pp. 11 16-21.

[8] E. Hay, J.J. Helesbeux. O.D.M. P. Grellier and P. Richomme. (2005). Antimalarial xanthones from Calophyllum caledonicum and Garcinia vieillardii. Life Science; 75, pp. 3077-3085.

[9] Q.X. Ze, W.B. Wlliam J.S. William, J Suling (Nov. 14, 2003). Antimicrobial Agents And Chemotherapy. American Society for microbiology.45 (5), pp. 1379-1386.

[10] A. Adewuji, O.H. Fasusi, R.A Oderinde. (2014). Antibacterial activityies of acetonides prepared from the seed oils of Calophyllum inophyllum and Pterocarpuys usun". J of acute medicine. 4(2), pp.75-80.

[11] I.A. Ajayi R.A. Oderinde, V.O. Taiwo and E.O. (2008). Agebedana. Short-term toxicological evaluation of Terminalia catapa, Pentackethra macrophyllaa and Calophyllum inophyllum seed oils in rats". Food Chemistry. 16, pp. 458-465

[12] L.M.S. Lemost, T.B. Martins, G.H. Tanajura, V.F. Gazoni, J. Bonaldo, C.L. Strada, M.G. Silva, E.L.D. Oglio, S.P.T. Juniou and D.T.O. Martin. (2012). Evaluation of antiulcer activity of cromanone fraction from Calophyllum barasiliense Camb. Journal of Etnopharmacology. 141, pp 432-443.

[13] M.B Zakaria, Vijaysekaran, Z. Ilham,N.A. Muhammad (2014). Antiinflammatory activity of Calophyllum inophyllum fruit extracts. Procedia Chemistry,13.pp 218-220.

[14] Y.C. She, M.C. Hung, T.W. Wang and Y.C. Chen. (2003). Inocalophyllins A, B and their methyl ester from the seed of Calophyllum inophyllum. Chemical and Pharmaceutical Bulletin. 51(7), I pp. 802-806.

[15] A. Al Temimi and R. Choudhary. (2013). Determination of antioxidant activity in different kinds of plant in vivo and in vitro by using diverse technical methods. J nut Food Sci.: 3, pp. 1-9. 
[16] I. Yohed I, R.A. Kristianita and S. Gunawan. (2017). Effect of Type of Solvent and Temperature in Total Phenolic Content, Total Flavonoid Content, and Antioxidant Activity Analysis In Nyamplung Leaves Extract (Calophyllum inophyllum). https://repository.its.ac. id/43646/1/2313100129_2313100155_Undergraduated_Theses.pdf. [Āugust 19,2021].

[17] L. Ghasemia, Y. Ghasemia and M.H. Ebrahimsade. (2009). Antioxidant activity, phenol and flavonoid content of 13 citrus species peels and tissues. Pak J pharm .Sci,, 22, pp. 277-281.

[18] AA Elzaawely and S. Tawata. (2012). Antioxidant capacity and phenoilic content of Remex dentatus L. grown in Egypt. J Crop Sci, Biotechnol. 15, pp. 59-64.

[19] C.K. Jose, F. Mathew and N. A. Aleykutty. (2018). Evaluation of In-Vitro Antioxidant Activity of Two Anti-Arthritic Plants by $\mathrm{DPPH}^{\circ}$ Method. International Journal of Innovative Science and Research Technology 3(9), pp. 249-253.
[20] E.O. Ojah, D.O. Moronkola, and P.M. Osamudiamen (2020). Antioxidant assessment of characterised essential oils from Calophyllum inophyllum Linn using 2,2-diphenyl-1- picrylhydrazyl and hydrogen peroxide methods. Journal of Medicinal Plants for Economic Development 4(1), a83.

[21] M. Da Silva Pinto, Y.L. Kwaon, E. Apostolide, F.M. Lajolo, M.I.Genovese and K. Shetty. (2008). Functional of bioactive compound in Brazalian strawberry (Fragaria $\mathrm{x}$ ananassa Duch). Cultivars: evaluation of hyperglycemia and hypertension potensial using in vitro models; J Agric .Foof Chem. 56(12),pp. 4386-4392.

[22] E.O. Ojah, D.O. Moronkola, and A.M. Akintunde. (2020). $\alpha$-amylase and $\alpha$-glucosidase antidiabetic potential of ten essential oils from Calophyllum inophyllum Linn. Iberoamerican Journal of Medicine 04, pp. 253-260. 